Tomasz Lesicki

Gdański Uniwersytet Medyczny

\title{
Proces rytualny i świat wyobrażony na festiwalach muzycznych
}

\begin{abstract}
Wstęp
Przystanek Woodstock i Heineken Open'er Festival to obecnie najpopularniejsze imprezy muzyczne $\mathrm{w}$ Polsce, przyciągające setki tysięcy uczestników. Przez kilka dni na wydzielonych terenach obrzeży miast, w których są organizowane, tworzą się miasteczka festiwalowe, stanowiące pole do socjologicznej analizy. Długość trwania festiwali, ich specyficzny klimat oraz liczba uczestników powodują, że nie są to „zwyczajne”, weekendowe imprezy organizowane w centrach miast. Zaprezentowane badanie miało na celu przybliżenie ich charakteru $\mathrm{w}$ perspektywie przedłożonych teorii.
\end{abstract}

\section{Teoria}

\section{Koncepcja obrzędu przejścia}

Podczas procesu rytualnego jednostka przechodzi ze sfery świeckości (profanum) do sfery boskości (sacrum). W uczestniku zachodzą zmiany, dzięki którym zyskuje nowe kompetencje kulturowe. Proces ten był przedmiotem dogłębnej analizy Arnolda van Gennepa (2006), antropologa lansującego tezę podziału społeczeństw na świeckie i religijne, a otaczającej te społeczeństwa rzeczywistości na domeny sacrum i profanum. Przemiana neofity, uczestnika obrzędu, moment nadawania mu nowego statusu według badacza najpełniej objawia się w obrzędzie inicjacji.

Rytuał przejścia - bo tak również się go określa - można podzielić na trzy fazy: preliminalną, liminalną i postliminalną (od słowa limen - próg). Van Gennep postulował, że każdy rytuał charakteryzuje się takim trójpodziałem. Pierwsza faza polega na wyłączeniu - podczas jej trwania najistotniejsze jest fizyczne odseparowanie inicjanta od bliskiej mu rzeczywistości społecznej oraz od norm i konwencji społecznych. Faza liminalna jest momentem zawieszenia tychże praw kultury i społeczeństwa (to faza funkcjonowania na progu dwóch światów, sacrum i profanum), w którym dochodzi do rytualnego przejścia, zetknięcia się ze sferą boską. 
Następujące po niej ponowne włączenie uczestnika obrzędu do świata profanum, wraz z jego konwencjami i ustalonym porządkiem, to ostatni etap procesu rytualnego. Zmarginalizowana $\mathrm{w}$ chwili separacji jednostka, wskutek działania na nią rytuału, powraca do zdefiniowanej struktury społecznej z nowymi kompetencjami kulturowymi.

Grupę społeczna, która konsoliduje się w trakcie rytuałów przejścia (o ile nie mają one charakteru indywidualnego), Victor Turner (2004) określił jako communitas. W ramach tego tworu zostają zawieszone zinstytucjonalizowane formy, dąży się do maksymalnego odejścia od strukturalnych ram. Elżbieta Hałas (2007) dostrzega, że podczas obrzędu w grupie inicjantów dochodzi do wręcz ekstatycznego poczucia wspólnotowości. Odarcie współuczestników rytuału z praw, obowiązków i konwenansów, według których żyli przed obrzędem, sprawia, że communitas jawi się jako homogeniczny twór pozbawiony przeszłości i przyszłości, jako „czysta nicość” (Turner 2005). Inicjanci znajdują się w rzeczywistości będącej antystrukturą, czyli specyficznym polem społecznym, w którym normy, status, ranga czy pozycja ulegają rozluźnieniu, jeśli nie rozpadowi, a ustalonym konstrukcjom społecznym zostają przeciwstawione ich negacje. Zamiast niezmienności mamy do czynienia z przejściowością, w opozycji do nierówności społecznych stawia się równość wszystkich, system nazewnictwa znika na rzecz anonimowości, a laickość zostaje zastąpiona przez świętość. Osiągnięcie sfery sacrum to w wypadku rytuału głęboka integracja - umożliwia całej społeczności silne zjednoczenie, redefinicję struktury społecznej.

W niniejszej pracy przyjęto, że można przełożyć omawiane teorie na grunt uczestnictwa w festiwalu muzycznym pojmowanym jako bardzo specyficzny rytuał przejścia, gdzie miejscem odseparowania jest teren imprezy, inicjantami jej uczestnicy (tworzący communitas), a wszelkie akty odbywające się w jego trakcie elementami procesu inicjacji.

\section{Teoria wymiany}

Funkcjonowanie w obrębie tej samej płaszczyzny wymaga od uczestników rytuału nawiązywania między sobą specyficznych relacji, które charakteryzują communitas. Jedną z nich jest wymiana i związane z nią obowiązki - dawania, przyjmowania i odwzajemniania daru (Mauss 2001). W teorii wymiany Marcela Maussa bardzo istotna jest symetria poszczególnych aspektów wymiany. W jej ramach funkcjonuje również system świadczeń całościowych polegający na tym, że przedmiotami wymiany są nie tylko rzeczy materialne, ale również dobra niematerialne, usługi, zachowania, uprzejmości i zabawa.

\section{Świat wyobrażony}

Uzupełniając analizę antropologiczną o paradygmat fenomenologiczny, warto zwrócić uwagę na pierwotne typizacje dokonywane przez jednostkę w procesie porządkowania świata, w którym żyje. Członek społeczności uznaje jednostkowe doświadczenia (swoje lub innych członków) za doświadczenia wspólne, przeżyte przez całą wspólnotę. Proces ten jest wspomagany przez korzystanie z wiedzy "przodków”, znaczących Innych, będących częścią społeczności. Jednostka 
swobodnie posługuje się tą wiedzą podczas interakcji z innymi członkami grupy, zakładając, że dysponują oni tym samym zasobem. Dokonując typizacji, jednostka przydziela pozostałych członków interakcji do kategorii „uogólnionego Innego" (przedstawiciela społeczności), który pełni funkcje ściśle związane z przypisaną mu rolą. Jednocześnie, w celu dopasowania, rola nadana przez jednostkę towarzyszom interakcji, zostaje zinternalizowana na nią samą (Lejzerowicz-Zajączkowska 2003). W trakcie trwania festiwalu muzycznego zatem osoba postrzega siebie i innych jako część społeczności uczestników festiwalu, podzielającej swoiste, zbiorowe doświadczenie.

W fenomenologicznej analizie festiwale muzyczne mogą być ujmowane jako specyficzne mikroświaty, których ideę wykorzystał w socjologii Alfred Schütz (Schütz za: Manterys 1997). Idea ta ma dwa składniki: obiektywny, w którym zawarto całą kulturowo sformułowaną rzeczywistość, i subiektywny, zawierający osobiste przeżycia i wyobrażenia jednostki związane z otaczającą ją rzeczywistością. Ze składników tych wyłania się charakterystyczna intersubiektywność przeżywanego świata, gdzie wizja danego konstruktu jest podzielana przez uczestników interakcji, chociaż w dalszym ciągu jest ona właściwa dla każdej jednostki z osobna.

Oba elementy uzupełniają się wzajemnie i tworzą ramę analityczną, według której będzie badany świat imprez masowych. Z jednej strony bowiem jest widoczny już „nadany” konstrukt społeczny, a więc ogólna charakterystyka danego festiwalu, a z drugiej strony został on stworzony na drodze subiektywnego poglądu jednostek. Można w tym przypadku mówić o możliwej intersubiektywności, wizji podzielanej przez ogól, ale w dalszym ciągu bardzo specyficznej dla każdego z osobna. Wizja ta przybiera formę zbiorowego ducha, charakterystycznej dla festiwalu kolektywnej świadomości, wytwarzanej w procesach komunikacyjnych i interakcjach między uczestnikami festiwalu. W tym ujęciu indywidualne doświadczenia jednostki, ich subiektywne interpretacje zostają przełożone na doświadczenia pozostałych uczestników rzeczywistości społecznej. Ponadosobowa świadomość będzie tworem indywidualnym, jednakże podzielanym przez ogół, uznanym za identyczny. Świadomość tej intersubiektywności kształtuje przeżywany świat (Lebenswelt), którego doświadcza każdy członek interakcji (Schütz 1989). Uczestnicy festiwalu mogą więc dzielić wspólny strumień świadomości.

\section{Cel i metoda}

Celem badań jest analiza osobistych poglądów uczestników festiwalu na temat tego szczególnego typu rozrywki. Chodziło o wyjście od jednostkowych doświadczeń imprezowiczów do próby uchwycenia generalnych tendencji związanych z przeżywaniem wydarzeń ujętych w socjologicznej analizie. Metoda ta umożliwiła precyzyjną kontrolę spływających informacji oraz kreację trafnego obrazu rzeczywistości społecznej. Najbardziej interesujące wydały się motywy uczestnictwa w obydwu imprezach, dostrzeżenie ich specyficznych wyróżników oraz miejsc wspólnych.

Projektując przebieg badania, postawiono następujące pytania:

1. Jakie procesy rytualne przejawiają się na poszczególnych festiwalach? 
2. Jak przedstawia się świat wyobrażony z punktu widzenia uczestników festiwali?

3. Jakie są punkty styczne danych festiwalów?

4. Czy uczestnictwo w festiwalu w jakiś sposób zmienia jednostkę? Jaka jest trwałość zmian w niej zachodzących? Czy jednostka na festiwalu staje się bytem liminalnym?

5. Jak przejawia się struktura (antystruktura) podczas festiwalu?

6. Jak przejawia się poczucie wspólnotowości w trakcie trwania festiwalu?

Do badań wykorzystano pogłębione wywiady jakościowe, a także obserwację uczestniczącą. Przepytano ośmiu uczestników festiwali muzycznych - trzech bywalców Przystanku Woodstock, trzech bywalców Open'era, a także dwie osoby uczestniczące w obydwu festiwalach. Badacz trzykrotnie wybrał się na Przystanek Woodstock (w latach 2008, 2009 i 2011) oraz dwukrotnie uczestniczył w Open'erze (w latach 2010 i 2015). Ustrukturalizowany wywiad z bezpośrednimi uczestnikami imprez pozwalał uchwycić autentyczne oblicze tych zjawisk. Analiza jakościowa zebranego materiału umożliwiła wytworzenie trafnego obrazu wycinka rzeczywistości społecznej, jakim są festiwale muzyczne.

\section{Wyniki}

\section{Motyw przyjazdu}

Motywy pierwszego przyjazdu na Przystanek Woodstock zwykle wiążą się z ciekawością. Respondenci sygnalizowali, że chcieli przeżyć coś nowego. Obydwa festiwale odbywają się w okresie letnim, więc uczniom i studentom (bo takich osób jest na festiwalach muzycznych najwięcej) łatwo o wygospodarowanie kilku dni wolnego, a także spontaniczne decyzje o wyjeździe. „Spotkałem się z kolegą na plaży i z K. w Sopocie, i to było tak zupełnie spontanicznie, rzucił, że jedzie na Woodstock za dwa dni, i czy jadę z nim. My się następnego dnia z K. ogarnęliśmy, co to Woodstock, w przeciągu drugiego dnia za ile, i już jechaliśmy".

Poza chęcią zaspokojenia ciekawości ważnym motywem jest również dążenie do weryfikacji legendy festiwalu. Chodzi tutaj zarówno o wydarzenie muzyczne ze stosunkowo długą historią, jak i fakt, że jest organizowane przez Jurka Owsiaka. „Zawsze chciałem jechać, bo zawsze podziwiałem Owsiaka za to, co robi, i chciałem go zobaczyć, bo dużo słyszałem o tym festiwalu, i namówił mnie kolega, który był rok wcześniej już z koleżanką, i powiedzieli, że jest fajna zabawa, ludzie, koncerty, i dlatego wybrałem się w podróż".

Ostatecznie motywem przyjazdu jest chęć spędzenia kilku dni w niekoniecznie wyszukanej, ludycznej atmosferze swobody i wolności. Co ciekawe, pragnienie totalnego odpoczynku i „luzu” wydaje się motywem ważniejszym od samej muzyki. „Jak kogoś to interesuje, to idzie, jak ktoś ma to gdzieś, to może nie trafić na żaden koncert jak K., który ani razu nie dotarł pod scenę, był chyba tylko na [...] Steczkowskiej chyba, to tam dotarliśmy tak dla beki tylko". Muzyka oczywiście jest istotna, buduje tło i determinuje do pewnego stopnia rodzaj osób przybywających na festiwal, ale podstawowym motywem uczestniczenia w imprezie jest możliwość odcięcia się od rzeczywistości i odreagowania. „[Ludzie - T.L.] 
jadą tam odpocząć, nie muszą się martwić o to, że wstaną rano, żeby ubrać się rano [...]. Jestem wolny, nikt mi nic nie nakazuje, robię to, co chcę; odpocząć, pobawić się inaczej, nie, kiedy idę na miasto się pobawić, do klubu".

W ciągu tych kilku dni spontanicznie zawiązujące się communitas pragnie uciec od codziennego życia. „Bo nie o gwiazdorstwo na Przystanku chodzi. Chodzi o dobrą zabawę przy niekoniecznie dobrej, ale radosnej, optymistycznie nastrajającej, ludycznej muzyce" (Owsiak, Skaradziński 2010: 37). Innym wyraźnie zaznaczającym się elementem jest potrzeba zawiązywania spontanicznych, przyjacielskich relacji z przypadkowo napotkanymi uczestnikami. „Na Woodstocku każdy jest kumplem, ludzie się obejmują, zachowują jak wielka rodzina”.

Wśród motywacji przyjazdu na Open'era na pierwszy plan wybija się chęć przeżycia koncertu gwiazdy. Decydując się na udział w tym festiwalu muzycznym, uczestnicy lustrują line-up, spis występujących artystów.

Przede wszystkim mieliśmy przy sobie folder open'erowy, w który organizatorzy wszystkich zaopatrują, i mogliśmy przejrzeć sobie tabelę, na której rozpisane było dokładnie, kto, kiedy i gdzie jest, i sobie dobieraliśmy. Ze względu na to, że wykonawcy występujący są znani o wiele wcześniej, można się doedukować, sobie przesłuchać czegoś, czego nie znaliśmy wcześniej, i zorientować się, czy pasuje, czy nie. Na ogół oczywiście kierowaliśmy się znanymi i lubianymi zespołami.

Festiwal jest oceniany na podstawie tego, kogo można na nim zobaczyć. „Miarą tego, czy festiwal jest dobry, jest to, jacy muzycy przyjeżdżają. To nie jest tak, że festiwal jako wartość sama w sobie jest czymś dobrym [...]. Na Selectorze byłam raz, może dwa razy, teraz nie jadę, bo po prostu jest słaby [...]". Co istotne, wybija się tutaj jednocześnie dążenie do zaliczenia maksymalnej liczby koncertów.

Wiesz, na Heinekena to akurat pojechałem, bo grało Sex Pistols, koncert takiej legendy to musiałem zaliczyć. Tak samo na Prince'a, chociaż go nie słucham. Potem się okazało, że jeszcze gra Gentleman i Eryka Badu, więc bardzo fajnie się złożyło na ten dzień. Na Heinekena to idę, jeśli gra coś fajnego, na Wooda to nie idzie się dla koncertów, tylko dla klimatu, znajomych i zabawy.

\section{Dojazd na festiwal}

Wspomnianej wolności w przypadku Przystanku po raz pierwszy doświadcza się podczas podróży na festiwal, którą większość uczestników odbywa w specjalnie podstawionych pociągach. To pierwsza ze sposobności wejścia inicjanta w antystrukturę festiwalu. "Sodoma i Gomora w pociągu [...] wypuścić wszystkich ze smyczy i wpuścić do tego pociągu i już czujesz tę wolność. Zaczynasz hardkorową imprezę".

Podróż na miejsce odosobnienia jawi się tutaj jako faza preliminalna obrzędu przejścia, gdzie uczestnicy odcinają się od rzeczywistości, w której żyją na co dzień. Już na tym etapie między uczestnikami zawiązują się towarzyskie relacje. Tak opisuje to $\mathrm{w}$ felietonie jeden respondentów:

O dziesiątej wieczorem stałem na peronie, czekając na podstawienie woodstockowego pociągu. Gdy pociąg podjechał, załadowałem się do niego od razu. Trzeba tu wspomnieć o tym, że czułem się trochę nieswojo, jadąc sam, bez swojego znajomego (nie 
czułem jeszcze wtedy woodstockowego klimatu). Jakie było moje zdziwienie, gdy już na wejściu grupa młodych ludzi spytała mnie, czy jadę sam. Zgodnie z prawdą odpowiedziałem twierdząco. - To jedziesz z nami! - usłyszałem. Cała, ponad ośmiogodzinna podróż (mieliśmy kilka niezapowiedzianych przystanków na hamulcu ręcznym, gdyż toalety miały zbyt małą przepustowość), minęła na śpiewaniu, w miarę możliwości na tańczeniu i - nie ukrywam - piciu alkoholu (Szkarłat 2010: 14).

Ważną rolę odgrywają tu uczestnicy z większym stażem - są szczególnego rodzaju przewodnikami, którzy umożliwiają nowo przybyłym inicjantom wdrożenie się w communitas. Mimo życzliwości innych uczestników droga na festiwal jest długotrwałym i uciążliwym procesem. Po przybyciu do Kostrzyna nad Odrą uczestnicy muszą dotrzeć na właściwe pole festiwalu, oddalone kilka kilometrów od centrum miasta. Innymi słowy muszą dostać się do faktycznego miejsca odseparowania, gdzie odbędą się kolejne elementy rytuału. Większość uczestników Open'era dojeżdża w okolice festiwalu specjalnymi autobusami, a aby dostać się na pole festiwalowe, również muszą odbyć kilkudziesięciominutowy marsz.

\section{Pole festiwalowe}

Poczucie wspólnotowości między uczestnikami festiwalu jest obecne przez całą imprezę, co w perspektywie obrzędu przejścia jest umownym poziomem „makro", natomiast najłatwiej je zaobserwować przy okazji dojazdu na festiwal i w trakcie trwania koncertów.

Po dotarciu na miejsce kolejne oddziaływanie sacrum na uczestników odbywa się za pomocą pola namiotowego. „Widok pola porusza, obrzydza ten brud, nagość, pijaństwo, pierwsze dwie godziny to szok, potem już wdrażasz się w atmę, wchodzisz w tryb, normalka". Aby w całości przeżyć festiwal muzyczny, poczuć jego atmosferę, należy skorzystać z pola namiotowego. Bez niego odbiór imprezy będzie niekompletny, straci na wartości.

Dlatego ludzie zaczęli chodzić pod namioty, żeby nie wracać do domu. Wydaje mi się, że tego ludzie poszukują. Szukają muzyki, ale co innego pójść na koncert gwiazdy, którą się lubi, a co innego zobaczyć ją na festiwalu. Dzięki polu namiotowym czuję się jak na wakacjach, nie mając pola namiotowego czuję się tak, jakbym wracała codziennie z imprezy.

Pole namiotowe to przestrzeń towarzyskich kontaktów, nawiązywanych lub podtrzymywanych podczas imprezy.

Wynajmuję pole namiotowe, ale tylko ze względów towarzyskich, zazwyczaj robię tak, że śpię i myję się u babci, która mieszka w centrum Gdyni, a kupuję bilet na polu i tak, żeby móc wejść na pole, tam większość znajomych, którzy przyjeżdżają z całej Polski jest rozbita, inaczej nie miałabym możliwości, żeby tam z nimi posiedzieć, pogadać. 


\section{Koncert - faza liminalna}

Koncerty są rdzeniem każdego festiwalu muzycznego. O ile respondenci zwłaszcza uczestnicy Przystanku Woodstock - podkreślali, że klimat oferowany przez festiwal jest nieraz ważniejszy od samej muzyki, o tyle punktami kulminacyjnymi każdego dnia imprezy są właśnie występy gwiazd. To podczas koncertów najwyraźniej można dostrzec proces rytualny wraz z jego fazą liminalną. Wtedy to publiczność najsilniej odczuwa obcowanie ze sferą sacrum. Uczestnicy, którzy znaleźli się na czas widowiska pod sceną, są w sytuacji progowej (limen), zawieszenia określonych konwenansów społecznych (antystruktura). Ekstatyczna atmosfera udziela się większości zgromadzonym, natomiast po koncercie, gdy na chwilę wracają do struktury, jest czas na skomentowanie występu. „W trakcie koncertu przeżywam go w głębi mojego serduszka, po koncercie komentuję, co się podobało, co nie". Doświadczanie sfery sacrum podczas koncertu może odbywać się indywidualnie, natomiast badani zwracają uwagę również na zbiorowość tego aktu. „Na koncercie wszyscy zachowują się jak jedna wielka rodzina”.

Właśnie zawiązanie ducha zbiorowego wynikające z obecności na koncercie masy podobnych do siebie ludzi jest punktem kulminacyjnym. Wspólny strumień świadomości przejawia się $\mathrm{w}$ akcie nabywania tego samego doświadczenia, przy wyłączeniu strukturalnych ram. To, co postrzega jednostka, jawi się jej jako wizja podzielana przez ogól. Indywidualna świadomość zostaje tutaj czasowo wyłączona na rzecz czegoś, co można nazwać świadomością ponadosobową. Nawet jeśli koncert jest przeżywany indywidualnie, jego odbiór w masie innych uczestników czy dyskusja na jego temat jest aktem obiektywizacji tego doświadczenia, ukonstytuowaniem specyficznego Lebensweltu, na którym opiera się intersubiektywność świata festiwalowego.

Podczas trwania koncertu dochodzi również do specyficznego aktu wymiany, zwłaszcza na linii artysta-publiczność, gdzie - biorąc pod uwagę system świadczeń całościowych - wykonawcy otrzymują aprobatę publiczności w postaci oklasków, okrzyków, zabawy tłumu. Zrytualizowana wymiana nie musi mieć wymiaru transakcji ekonomicznej. Muzycy zatem wręczają w darze swój występ, a publiczność odwzajemnia ten akt entuzjastycznym odzewem. Wyjątkowy, udany koncert zwykle kończy się owacją tłumu i domaganiem się bisu. W tym układzie okrzyki, oklaski są darem, który artyści muszą przyjąć, a następnie odwzajemnić. Koncepcja Maussa sprawdza się tutaj, kiedy muzycy podczas bisu dają od siebie coś nietuzinkowego, niepowtarzalnego, zatem oddają dobro z nawiązką.

[...] a potem tak klaskali, że Pollard wyszedł jeszcze raz sam z gitarą, i odegrał jeszcze jeden utwór, no i było super, to było takie magiczne.

Fantastyczne improwizacje nawet były, na telebimach wyświetlono tekst kawałka Knights of Cydonia, gdzie się skanduje pewne kwestie i to było bardzo fajne, bo wokalista nawiązywał kontakt $\mathrm{z}$ widzami i prosił ich, żeby śpiewali razem z nim. [...] wszyscy szaleli, ja byłam dość blisko sceny z moją przyjaciółką i nawet to błoto, które nas ochlapało po kolana, w ogóle nie miało żadnego znaczenia. 
Specyficzną formą zawieszenia norm społecznych w sytuacji koncertu jest pogo - obecne zwłaszcza na koncertach rockowo-metalowych. Agresywny niby-taniec polega na pozornej bijatyce uczestników koncertu w rytm granej muzyki. Agresja i przemoc bardzo często pojawiają się podczas rytuałów przejścia, kiedy to inicjanci są bici czy wręcz okaleczani (Gennep 2006; Eliade 1997).

To nie ma jakiejś głębszej ideologii w tym, po prostu jakoś mnie to bawi. W sumie czuje się taką kontrolowaną agresję, nie wiem, mi się to podoba na przykład wejść w to pogo z taką agresją. Nie z nienawiścią do tych ludzi, tylko jakąś taką wewnętrzną agresją poruszać się w ten sposób, który nikogo nie dziwi i w zasadzie być niezależnym od sądów, opinii innych.

Mimo brutalności tego aktu jego uczestnik godzi się na naruszenie swojej nietykalności, aby samemu móc wyładować w ten sposób pokłady energii, napięcia. Co ciekawe, respondenci niejednokrotnie mówili o pewnym braterstwie, nici porozumienia między uczestnikami pogo. „Byłbym bardziej skory pomóc komuś na pogo, niż komuś, kogo spotkam na ulicy. Jakoś tak bliższy jest. Chyba w jakimś jednym konkretnym aspekcie życia się zgadzamy". Zachowanie jednostek $\mathrm{w}$ trakcie pogo jest praktycznym zastosowaniem zasobu wiedzy wypracowanej przez znaczących Innych. Fenomenologiczna mądrość przodków jest wspólna wszystkim inicjantom, którzy mimo to są anonimowi względem siebie. Idea pogo, stworzona przez pewnego Innego, przeważyła nad innymi modelami zachowań i taki układ został zaakceptowany przez ogół. „W pogo idę się wyżyć. Czuję wtedy tożsamość z tłumem".

Domeną wielu festiwali - między innymi Woodstocku - jest wszechobecny brud. Przystanek często jest nazywany - zwłaszcza przez jego przeciwników „Brudstockiem”. Konieczność zrezygnowania z niektórych zwyczajów higienicznych to kolejny argument przemawiający za antystrukturalnością festiwalu muzycznego. Co prawda, festiwale muzyczne oferują możliwość dokonania niezbędnych zabiegów higienicznych, lecz często w ograniczonej formie. Poza tym tumany kurzu i wysoka temperatura sprawiają, że wysiłki włożone w higienę są zwykle krótkotrwałe. Niemniej, towarzystwo innych uczestników imprezy, którzy są w takiej samej sytuacji, skutecznie wycisza kulturowy imperatyw czystości, wręcz wzmaga poczucie wolności. Troska o wygląd, o odbiór przez innych powróci dopiero po zakończeniu imprezy.

Nie przeszkadza mi, bo jadę tam z nastawieniem, że będzie brudno. [...] Niemycie się jest po prostu wygodne. Nie musisz się pieprzyć z ręcznikami, myć włosów, budzisz się, kładziesz się jak chcesz, nikt nie zwraca ci uwagi, jak wyglądasz, że jesteś brudny. Nie przeszkadza mi to, ale nie chciałbym tak wyglądać, jak już wrócę z Woodstock.

W przypadku Przystanku Woodstock można mówić o pewnego rodzaju afirmacji brudu - jedną z atrakcji są tam błotne kąpiele. Nieopodal głównej sceny jest ustawiony wysoki słup, tak zwany grzybek, z którego tryska woda, zamieniając obszar wokół siebie w błotniste bajoro. Jest to miejsce zabaw, prostych gier i euforycznych kąpieli. W obrębie błota normy społeczne również ulegają rozprężeniu.

Wszyscy wydają się znać te obręby błota. Jak już ktoś się tam znajdzie, to można go legalnie ubrudzić, on nie będzie miał do ciebie pretensji, bo po to tam przychodzi, żeby 
się potaplać w błocie, i nawet, jeżeli tej osoby nie znasz, możesz ją spokojnie wrzucić i ona nie będzie miała do ciebie pretensji, się uśmiechnie i ciebie też wrzuci.

Ta forma zabawy może przypominać afrykańskie i australijskie rytuały przejścia, gdzie ciała inicjantów często są smarowane właśnie błotem. Brud nie jest tutaj elementem wykluczającym kontakt ze sferą sacrum, wręcz przeciwnie - biorąc pod uwagę tradycję obcowania z błotem i ekstatyczny charakter tego aktu, może stanowić do niej klucz. Koniec końców błoto, tak jak inicjant w fazie liminalnej, również jest formą w specyficznym stanie zawieszenia pomiędzy gęstą cieczą a rozrzedzonym ciałem stałym (Douglas 2007).

\section{Wnioski}

Po zakończeniu festiwalu muzycznego jego uczestnicy wracają do pełnienia różnorakich ról społecznych, z powrotem zanurzają się w strukturalnych ramach. Communitas rozwiązuje się tak samo szybko, jak się zawiązała, obrzęd przejścia dobiega końca. Impreza masowa tego typu okazuje się być rzeczywistym przecinkiem, progiem występującym pomiędzy prawami struktury.

Wyjątkowość festiwalowej muzyki polega na tym, że jest silnie osadzona w klimacie, który oferuje dany festiwal, w rzeczywistości społecznej stworzonej w trakcie jego trwania. Odbiór muzyki jest zapośredniczony poprzez zbudowany na festiwalu świat wyobrażony, z którym można się utożsamić (Frith 2011). „Nie przeszkadza deszcz, bo jest muzyka. To jest takie spoiwo”. Festiwale muzyczne, Open'er czy Woodstock, dają subiektywne poczucie przynależności. Umożliwiają ekspresję jego uczestników w ustalonych ramach, a obecna muzyka pozwala określić siebie, a także doświadczyć w rytualny sposób zbiorowej tożsamości.

\section{Literatura:}

Douglas M., 2007, Czystość i zmaza, tłum. M. Bucholc, Warszawa: PIW.

Eliade M., 1997, Inicjacja, obrzędy, stowarzyszenia tajemne: narodziny mistyczne, tłum. K. Kocjan, Kraków: Znak.

Frith S., 2011, Sceniczne rytuaty: o wartości muzyki popularnej, tłum. M. Król, Kraków: Wydawnictwo Uniwersytetu Jagiellońskiego.

Gennep A. van, 2006, Obrzędy przejścia. Systematyczne studium ceremonii, tłum. B. Biały, Warszawa: PIW.

Hałas E., 2007, Konwersja. Perspektywa socjologiczna, Warszawa: Wydawnictwo Naukowe Scholar.

Lejzerowicz-Zajączkowska B., 2003, Człowiek w świecie sensów. Filozoficzne podstawy fenomenologicznej socjologii Alfreda Schütza, Płock: Wydawnictwo Naukowe Novum.

Manterys A., 1997, Wielość rzeczywistości w teoriach socjologicznych, Warszawa: PWN.

Mauss M., 2001, Socjologia i antropologia, tłum. M. Król, K. Pomian, J. Szacki, Warszawa: Wydawnictwo KR.

Owsiak J., Skaradziński J., 2010, Przystanek Woodstock. Historia najpiękniejszego festiwalu świata, Warszawa: Świat Książki.

Schütz A., 1989, Fenomenologia i nauki społeczne [w:] Fenomenologia i socjologia: zbiór tekstów, red. Z. Krasnodębski, Warszawa: PWN. 
Szkarłat M., 2010, Przystanek Woodstock. Przygoda na cate życie, „Magazyn Literacki Aha! Głos Młodych" nr 165.

Turner V., 2004, Liminalność i Communitas [w:] Badanie kultury. Elementy teorii antropologicznej. Kontynuacje, red. M. Kempny, E. Nowicka, Warszawa: PWN.

Turner V., 2005, Gry społeczne, pola i metafory. Symboliczne dziatanie w społeczeństwie, Kraków: Wydawnictwo Uniwersytetu Jagiellońskiego.

\begin{abstract}
Abstrakt
Artykuł dotyczy festiwali muzycznych Przystanek Woodstock i Heineken Open'er Festival ujętych $\mathrm{w}$ paradygmacie antropologicznym i fenomenologicznym. Poprzez obserwację uczestniczącą i wywiady jakościowe dociekano przejawów procesu rytualnego obecnego na festiwalach, a także charakteryzowano specyficzny Lebenswelt, świat przeżywany z perspektywy ich uczestników. Celem naukowej analizy było uzyskanie pogłębionego wglądu w osobiste wizje uczestników festiwalu, w jaki sposób jawi się w ich oczach, a co za tym idzie - określenia funkcji pełnionej przez taką formę rozrywki. Istotne było poznanie motywów uczestnictwa w imprezie masowej oraz sposobu postrzegania siebie w ludzkiej masie przez innych imprezowiczów. Interesujące były jednostkowe doświadczenia i idąca za nimi możliwość przełożenia ich na doświadczenie zbiorowe. Doświadczenie jednostek zbadano z punktu widzenia procesu rytualnego w ujęciu Arnolda van Gennepa i Victora Turnera, procesów wymiany opartych na teorii Marcela Maussa, a także doświadczania zbiorowej tożsamości (intersubiektywność przeżywanego świata) mającej rodowód w koncepcjach fenomenologicznych Williama Jamesa i Alfreda Schütza. W wyniku analizy odkryto, że na festiwalach muzycznych są obecne mechanizmy tożsame z rytuałami inicjacji, a imprezy charakteryzuje antystrukturalność przejawiająca się w specyficznym zawieszeniu niektórych norm społecznych. Wymiana dotyczy przede wszystkim niematerialnej sfery na płaszczyźnie uczestnicy-artysta. Idea Lebensweltu zasadza się przede wszystkim na wspólnym przeżywaniu następujących po sobie koncertów, które budują doświadczenie zbiorowe.
\end{abstract}

\title{
Słowa kluczowe
}

rytualność, świat wyobrażony, antystruktura

\section{Summary}

\section{Ritualised Process and Imaginary World of Music Festivals}

The article is concerning music festivals, Przystanek Woodstock and Heineken Open'er Festival recognized in anthropological and phenomenological paradigm. By attending observation and in-depth interviews, author inquired manifestations of ritual process and investigated specific Lebenswelt, the world experienced from the perspective of the participants. The purpose of scientific analysis was in-depth insight into personal visions about the festivals, the way they are concerned in eyes of their participants and what are the functions of this form of entertainment. It was important to investigate the motives to participate in such mass events, but also the perception of each other in the human mass of others. Author was concerning individuals' experiences and the way they were transforming into collective experience. It was assessed from the perspective of ritual process theory of Arnold van Gennep and Victor Turner, exchange theory of Marcel Mauss and the experience of collective identity based on phenomenological theories of William James and Alfred Schütz. The results shows presence of mechanisms identical with rites of passage 
and antistructure, manifested with specific suspend of certain social norms. The exchange relates primarily to the immaterial sphere, at the level of participants-artist, which clearly appears in the case of both events. Idea of Lebenswelt is based primarily on the joint experiencing consecutive concerts which builds collective experience.

\section{Keywords}

rituals, imaginary world, antistructure 
